\title{
DESCENDING MOUNTAIN ROUTES FUTURE: THE NORTH YUNGAS AND FĂGĂRAȘ GEOSYSTEM`S COMPARATIVE STUDY
}

\author{
Mihai VODA ${ }^{1}$, Yuri Sandoval MONTES ${ }^{2}$
}

DOI: 10.21163/GT_2018.132.12

\begin{abstract}
:
The Yungas region geographical position on the Eastern slopes of Cordillera Real and the Făgăraș Mountains East-West alignment generated unique Geosystems. A single gravel road links La Paz with Amazonia Boliviana: El Camino de la Muerte and only one road crosses the Făgăraș Mountains: the Transfăgărăşan. Mountain roads networks are connecting communities and their resources all over the world. This research is adding value to the old mountain roads systems using the new technical Geography advances and transforming them in tourist sites. The cultural ecosystem services have a growing popularity that can be valorized for the locals benefits if managed accordingly. This paper focuses on the special descending sections identification and assessment for the mountain recreational activities development. The North Yungas and the Făgăraș areas represent unique Geosystems from the Bolivian Andes and the Romanian Mountains, analyzed using Geomedia techniques. Here we show that our Death Road model can securely allow tourist access, increase locals' livelihood and protect mountain environments. Our research results prove that the South American Geosystem`s unique attributes can constitute a functional reference for a considerable number of world`s mountain routes future sustainable development.
\end{abstract}

Key-words: Geomedia, Smartphone, Ecosystem services, Geosystem, Transfăgărășan; Yungas.

\section{INTRODUCTION}

The North Yungas Geosystem reflects changes in the field of community-based tourism by presenting new research approaches using the smartphone's Android emerging technologies. The Death Road frame model developed with Geomedia techniques will help mountain communities around the world to mitigate their poverty problems. It provides insight into the mountains' natural resources virtual exploitation issues. The Geomedia techniques are using the digital geo-information from different media sources (earth observing media such as Google Maps, Google Earth, social media such as Facebook and geo-located mobile apps) to virtually illustrate the unique characteristics of special geographical locations, spatially defined as Geosystems (Ernawati et al., 2018; Voda et al., 2017) and having a corresponding geodatabase (Nicoara and Haidu, 2011).

A considerable number of people are affected by poverty, struggling to survive in the mountains or leave. Currently, the increasing migration rate to the European developed countries is positioning Romania after Syria, which is in the midst of a civil war (UN DESA, 2017). The Bolivian mountains impoverished citizens are living in difficult conditions.

\footnotetext{
${ }^{1}$ Dimitrie Cantemir University, 540545, Targu Mures, Romania, mihaivoda@cantemir.ro;

${ }^{2}$ Universidad Mayor de San Andrés, Carrera de Ingeniería Geográfica, La Paz, Bolivia, ysandoval@umsa.bo.
} 
Bolivia`s human development index ranks $118^{\text {th }}$ out of 188 countries and territories (UNDP, 2016).

Valorizing the mountain roads potential for recreational activities constitute an environmentally friendly solution for the future as the cultural ecosystem services such as trekking, wildlife photographing or mountain biking, have become popular in the recent years (Newsome and Davies, 2009; Winters et al., 2011; Webber, 2007; Morckel and Terzano, 2014; Goeft and Alder, 2001). The Bolivian and Romanian policy makers have to take into account the creation and communication of the cultural ecosystem services knowledge (Fish, 2016; Voda et al., 2017). Community decision factors can administrate the designated sections and local inhabitants can contribute by offering accommodation, guiding and traditional farming experiences. The local organization, the self-control of the social networks and the innovative technology support represent the answers for the rural communities in search for alternative livelihood provided by the cultural ecosystem services development (Lew and Cheer, 2018; Ernawati et al., 2018).

The Death Road phenomenon proves our Yungas Geosystem theory in which the tourist flow constitutes the matter; the locals symbolize the energy while the internet, the social media and the smart apps represent the information input. Here we show the dynamic equilibrium between the matter, energy and information input and output fluxes, quantified by the Death Road recreational ecosystem services. The North Yungas functional attributes can be identified in the Făgăraș Geosystem and many other mountainous environments throughout the world. The mountain tourism characteristics, such as trails, gravel roads and guideposts are present in most of the world`s ranges with their wilderness subjugated by human intervention. Descending on mountain bikes in Bolivia represent an adventure recreational activity, geographically located in the Cordillera Real wilderness, which is generally characterized by dense tropical forest and steep slopes (Walter, 1982; Beedie, 2003).

The Death Road frame model has to stimulate new, important questions: how to educate local communities to keep the Geosystem balanced; which are the development acceptable limits, according to the local environment physical capacity of support? Our grounded theory was constructed based on Death Road phenomena to emphasize the value of the North Yungas Geosystem`s unique attributes and anticipate prospective changes in Romania and other world`s mountain communities.

A significant number of websites, social media and smartphone apps promote the Death Road (El Camino de la Muerte) route, located in Bolivia, which unites the snowy highlands above the seat of the country government (La Paz) with the Yungas region, in the jungle. It covers about 64 kilometers and exceeds a drop of more than 3,600 meters, starting on the tarmac road from the 4,470 meters of altitude. The pavement is left for the gravel and the width of the road is narrowed to a merely 3.2 meters, although there are sidings. Fog and rain are frequently registered along the jungle section with descending left side precipices of up to 800 meters of free fall (Camino de la Muerte, 2009).

Recreational ecosystem service development using the Geomedia techniques facilitate the opening of new mountain routes not only in Bolivia or Romania but anywhere in the world. As new technological advancements and especially smart applications are progressively seen as an answer for many ecosystem services and tourism activities development, it is efficacious to investigate their impact in Bolivia, which has the most famous descending mountain route in the world, the Death Road.

Various investigations have explored the subject, notably Sil et al. (2016), Kumar and Kumar (2008), Boyd and Banzhaf (2007), Sherrouse et al. (2011), Wimpey and Marion 
(2011), Wescott and Andrew (2015), emphasizing the importance of the world's mountainous regions in provisioning ecosystem services. The recreational experiences are quantifying people`s non-material benefits offered by different environments through the cultural ecosystem services (MEA, 2005; Sanna and Eja, 2017). Fish et al. (2016) advanced a relational approach to cultural ecosystem services, based on the human`s contact with the natural landscapes.

Buhalis and Law (2008) observed the smartphone applications linkage to the tourists' independent travels development. Schwanen and Kwan (2008) showed that modern technology facilitates the personal interconnection and leisure activities organization. Dickinson et al. (2014) argued that travellers have all the needed information about a destination in their smartphones. Martínez-Graña et al. (2017) proved that the local natural and cultural resources are considerably better protected and disseminated with the help of mobile phones smart applications. The geographical representation of various Geosystems evolved from paper maps to smartphone apps (Voda, 2013). Lapenta (2011) believes that Geomedia`s augmented reality displays our environmental features through the digital visualization systems. Ernawati et al. (2018) found that images with geolocation could be transformed into the Geosystem`s scientific illustration with the help of Geomedia techniques. Inal et al. (2017) showed the smartphones` GPS efficiency for the historical sites coordinates validation. Baiocchi et al. (2017), emphasized the Global Navigation Satellite Systems (GNSS) techniques relevance for the smartphones maps accuracy. The geolocated images and virtual maps sharing processes through the social media channels are controlling the Geosystem`s information and energy fluxes, interconnecting people and geographical spaces (Lapenta, 2011; Voda and Negru, 2015; Zheng et al., 2010).

Our study will show how Geomedia techniques were used to analyze the North Yungas Geosystem`s characteristics and future development capabilities. The Death Road tourist site can be a model for the virtual imagery elaboration of the Transfăgărășan road or other mountainous region`s descending routes. With the help of the new modern geographical technologies based on WebGIS, smart apps and geolocation, the mountain communities will identify their particular natural assets and transform them into emerging tourist sites.

\section{METHODOLOGY AND MATERIALS}

The geospatial indicators of the North Yungas and the Făgăraș Geosystems were identified based on available satellite imagery, regional bio-geographical maps, social media assessment and WebGIS analysis. The Cordillera Real gravel roads network were explored on motorbikes and mountain bikes in April-May 2017 and April 2018.

We analyzed, assessed and digitally processed the North Yungas and Făgăraş Geosystems`s natural and anthropogenic components. For both mountainous regions, the natural common attributes are represented by the towering peaks, deep valleys, steep rocky slopes and tumultuous river rapids. The anthropic interference with the mountains generated other standard characteristics such as rural settlements, passage roads, but also created the indigenous culture, which produced the unique functional attributes. Based on our Geosystem grounded theory where the inputs and outputs of matter, energy and information have to be constantly balanced in a dynamic equilibrium state, we used the Geomedia techniques to digitally transform and integrate all the relevant environmental components into virtual functional illustration of the analyzed geographical spaces (Mac, 1996). 
The field work of our exploratory research was carried out with Garmin GPS, Iphone8+ and Xiaomi Redmi 3S embedded geolocation systems for the data collection and spatial layers validation. The photos taken on the mountain trails registered the exchangeable image file (EXIF) data for the coordinate determination and mapping purposes.

The Geomedia technique incorporates the spatial geographical characteristics into virtual Geosystems where all the environmental components are interconnected. Following the human experience of the geographical space, the Geosystem`s elements were synthetized and transformed into visual imagery structures (Park and Santos, 2017). Furthermore, the multi-scale modeling process required the components assessment and the different attributes recognition. According to Haidu (2016), when operating with information from various levels, the characteristics of the Geosystem`s structure-components interrelation determination and the digital processing of geographical data is possible and generates the technical character of the research.

Google Maps ${ }^{\mathrm{TM}}$ and Google Earth datasets of the Cordillera Real sections, Coroico and Coripata were utilised for maps creation. The descending mountain tracks were charted on orthophoto maps and vectorized using satellite images of $30 \mathrm{~m}$ resolution from Google Earth, ESRI, EarthStar Geographics and the international GIS user communities. The Geomedia technique approach to the mountain communities' development contributes to the identification, evaluation and valorisation of the existent natural and cultural resources. The Geosystem grounded theory is based on the Death Road phenomena whose functionality will be validated by the new technological advancements, regulated and coordinated by the social networks and the smartphone applications. Our research scope was to design Geomedia techniques able to extend the Yungas Geosystem`s qualities and externalize its virtual representation functionalities.

\section{RESULTS}

Although the Bolivian North Yungas and Romania`s Făgăraş region integrate the common functional characteristics of the world's mountains, the international tourists are attracted to the areas by a unique Geosystem attributes, generated by a cumulus of internal and external factors.

The Yungas Geosystem`s special features were developed in time with the local and international media contribution, which amplified the hazardous factor associated with the specific rough geographical characteristics. Everywhere in the world, the creation of a future tourist site is fundamentally influenced by the media (Milne et al., 1998). Considering the physical challenges determined by the transition from altitudes of $4470 \mathrm{~m}$ in the Andes to $1000 \mathrm{~m}$ in the Amazon rainforest, the media virtual imagery was easily exaggerated. Before visiting a geographical location, people's mind generates naïve images about the place, built on collective conventional images (Cheriffi et al., 2014). The Death Road stereotypical image was constructed based on its unique functional attribute: dangerousness. The transformation of the most intriguing mountain road into a tourist site followed. The findings were evaluated; the North Yungas and the Făgăraș Geosystems attributes were determined and compared.

Formerly, there were no roads to the Yungas or the Amazon for motor vehicles, only routes on foot or "loin of beast", the best known was the path of "Choro". Apart from the Choro there are three other pre-Columbian roads, which are the Sillu Tinkara, the Huancané, and a third that leaves Challapampa. Currently covered by vegetation, each one has a rehabilitation project with no definite term. Despite being still used by automobile traffic, the 
old road to Coroico, named "El Camino de la Muerte" due to the number of vehicles that fall from it every year, now serves as a mountain bike trail for hundreds of tourists per year, who pay between 40 and 60 US \$ for the service to La Paz agencies. At the same time, Coroico has become in recent years a visited tourist center that has a wide range of services, including accommodation, restaurants and outdoor activities (Coroico, 2018). Haukeland et al. (2010) argues that recreation could be a motivational factor for adventure tourism.

\subsection{The North Yungas Geosystem}

The need to connect La Paz with the Yungas, an area located northeast of the La Paz city in the Central Andes, determined the road construction in a region dominated by dense wilderness, coca plantations and mountain ecosystems, in a very rainy climate and with frequent mists (Yungas, 2018).

El Camino de la Muerte is one of the most dangerous roads in the world, especially in the section that descends from La Cumbre $(4470 \mathrm{~m})$ to Yolosa for approximately $64 \mathrm{~km}$, the average of vehicles descending to the abysses of 800 meters is more than two a month. Imboden (2012) emphasized the risks importance in adventure tourism, stating that the experiences offered have to be presented as safe and secure in order to be desired. In 1995, the Inter-American Development Bank named La Paz to Coroico route "the world's most dangerous road." The international media started to contribute to the tourist site creation. This road was built by Paraguayan prisoners during the Chaco War in the 1930s. It is one of the few routes that connect the Amazon rainforest in the north with the rest of the country, following the former Inca Choro trail (Chaco, 2009).

The tourist Death Road (DR) starts on tarmac from the highest La Paz- Choro connection route, altitude of $4470 \mathrm{~m}$ (Tarmac Road_DR) descending for $32 \mathrm{~km}$ up to the gravel road (GR) section (DR_GR). Usually accompanied by a tourist guide from La Paz agencies, the biker groups learn this section rule of driving and proceed for another $32 \mathrm{~km}$ on gravel to Yolosa small community, the Death Road end point (DR_GR_end) (Fig. 1).

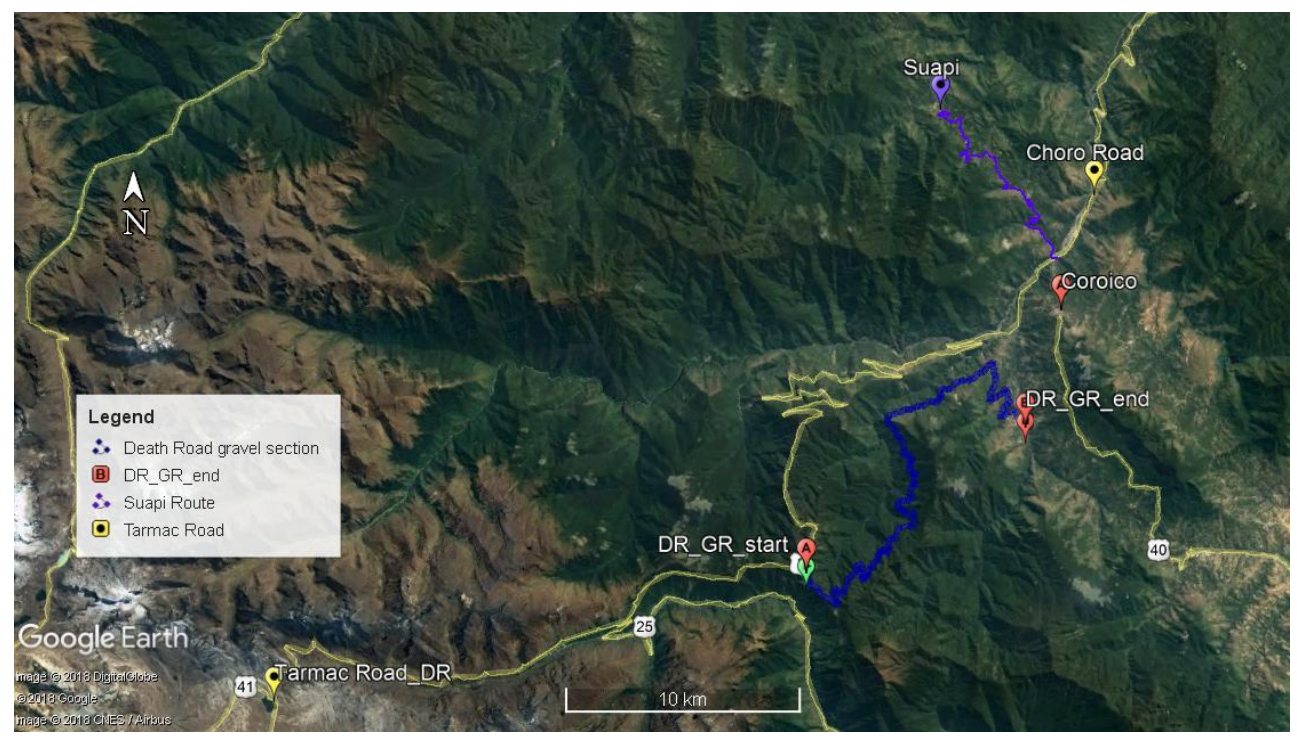

Fig. 1. The North Yungas Geosystem`s map with the Death Road extension (from Tarmac Road_DR to DR_GR_end). 
It was once the only way of communication between the Amazon Coca farms and the La Paz highlands, this meant that there was a huge traffic of people and mechanisms in both directions, mainly trucks and heavy buses, which had to make difficult maneuvers to pass on the road and many fell into the abyss. This is how it got its name: "the route of death".

Because Paraguayan prisoners of the Chaco War (in the 1930s) were the ones who built the road and then were thrown into the void, a legend tells that the prisoners cursed this road and promised to take souls to death with them. The legend was born and the countless accidents explained through a local mystical approach. The new two-lane road has 54 bridges and a slope stabilization number (The Death Road, 2018). When driving on this road the left must be maintained, (it is the only place in Bolivia where vehicles are driven on the left side) so that the drivers from the left side are able to observe more easily the edge of the road, which in almost all crossing places is an abyss, which can reach in some places $800 \mathrm{~m}$ vertically. The law indicates that the driver who drives up the hill (in the direction of La Paz) has priority over the one that goes down (in the direction of Choro), so the vehicle that descends must stop when another one climbs. In 2011 there were a total of 114 accidents (the second route with the most incidents in Bolivia after the road between La Paz and Oruro), with a total of 42 deaths (Blind Worlds, 2017).

The danger posed by this route made it a popular tourist destination since the 1990s. In particular, mountain bike enthusiasts use it for its steep descents and the exquisite scenery of the $32 \mathrm{~km}$ long gravel road section, from DR_GR_start to DR_GR_end (Fig. 2).

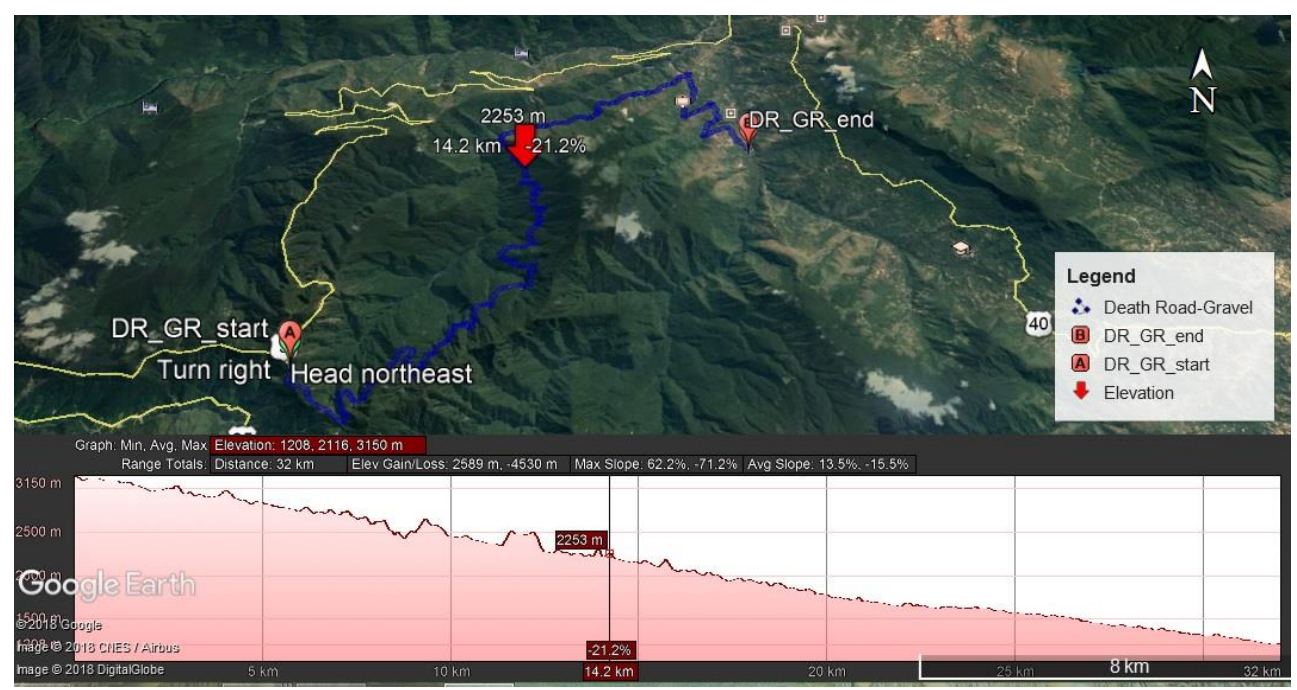

Fig. 2. The Death Road gravel sectors start (DR_GR_start) and finish (DR_GR_end) points.

The Death Road model is defined by the gravel road section which represents the quintessence of the North Yungas Geosystem. As one descends the Northern mountain slopes from $3150 \mathrm{~m}$ (DR_GR_start) to $1200 \mathrm{~m}$ (DR_GR_end) in Yolosa, the tourist groups constitute the matter input in the Geosystem. They pay a 25 Bolivianos (\$us 3,50) fee at the local community checkpoint. La Paz travel agencies generate the Geosystem's energy, providing means of transportation to the geographical location. Small resorts spread in the Río Coroico valley, therefore, after the mountain bike descent, the tourists interact with the 
locals, taste the local food and relax in the swimming pools before heading back to La Paz. The information flux is created on the social networks such as Instagram, Facebook and WhatsApp once the adventurers start sharing their experience. Although written details can be found in the LonelyPlanet, Fromer's, or Rough Guides pages, the modern tourists prefer the smartphone applications. Furthermore, the participants' opinion and pictures are counted and the virtual representations validated online by the reviews and rating systems (Ernawati et al., 2018).

Apart from El Camino de la Muerte, two other routes were identified in the North Yungas region. The first one is a gravel road that connects Suapi village to the Rio Coroico main valley and the second represents an Inca paved route that starts from Coroico settlement and penetrates the mountain dense forest down to the same river valley.

The Suapi route follows a left Coroico river tributary and crosses spectacular mountain ridges from $1000 \mathrm{~m}$ to $1650 \mathrm{~m}$ altitude along a $16 \mathrm{~km}$ long dirt road. Small forest sections, Coca plantations, beautiful meadows and majestic waterfalls can be admired on this alternative adventure route. Small community households are scattered in the Suapi track vicinity, easing the potential future tourist-local inhabitant interaction (Fig. 3).

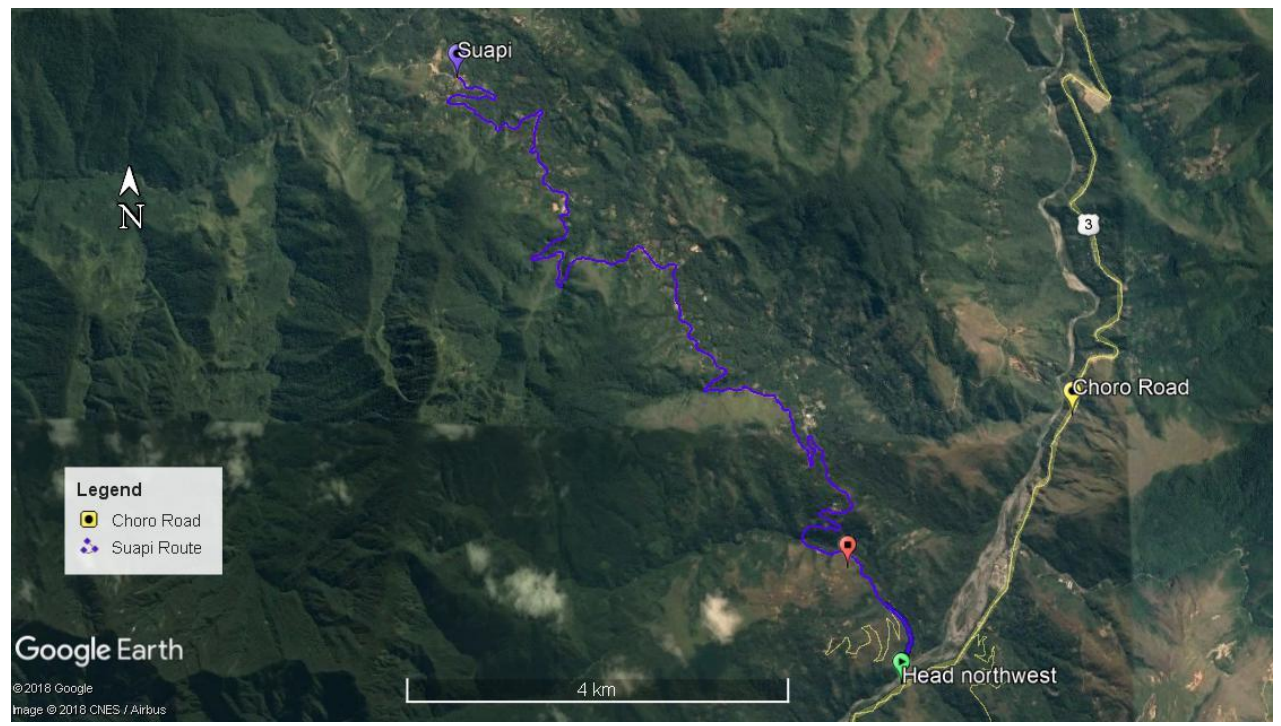

Fig. 3. The Suapi route potential development from Rio Coroico`s Choro road.

The Inca route that connects Coroico with the homonym valley consists of a narrow mountain track paved with rounded riverbed rocks. The common functional attribute of this route is represented by the mountain steep slopes and dense tropical forest characteristics. Dangerous under rainy conditions because of the slippery rocks, the Inca route from Coroico to the Coroico river valley is one of the unexplored sections of the North Yungas region (Fig. 4).

The Death Road model offers a different approach to the cultural ecosystem services development opportunities, taking into account all the nonconsumptive outputs of the North Yungas Geosystem. The Bolivian people`s comprehension of their Geosystem`s unique attributes functionality is giving rise to the mountain inhabitants well-being. 


\subsection{The Făgăraș Geosystem}

Romania`s Făgăraș Mountains represent the country`s highest range (2544 m on Moldoveanu Peak) forming a natural border between Transylvania and Walachia historical provinces. The Făgăraș Geosystem`s common attributes are illustrated by the glaciated alpine mountain range with dense forests, flat top ridges, sharp edged peaks, cirques and small troughs (Martonne, 1917). The Romanian shepherds' annual migration from Transylvania to the South conducted to the Făgăraş Geosystem unique attribute conservation: the ancient Romanian habits and peculiar customs. It is the quintessence of the Romanian national identity, validated by the distinctive Latin language preservation throughout the centuries of barbaric invader waves (Martonne, 1917; Mac, 1996).

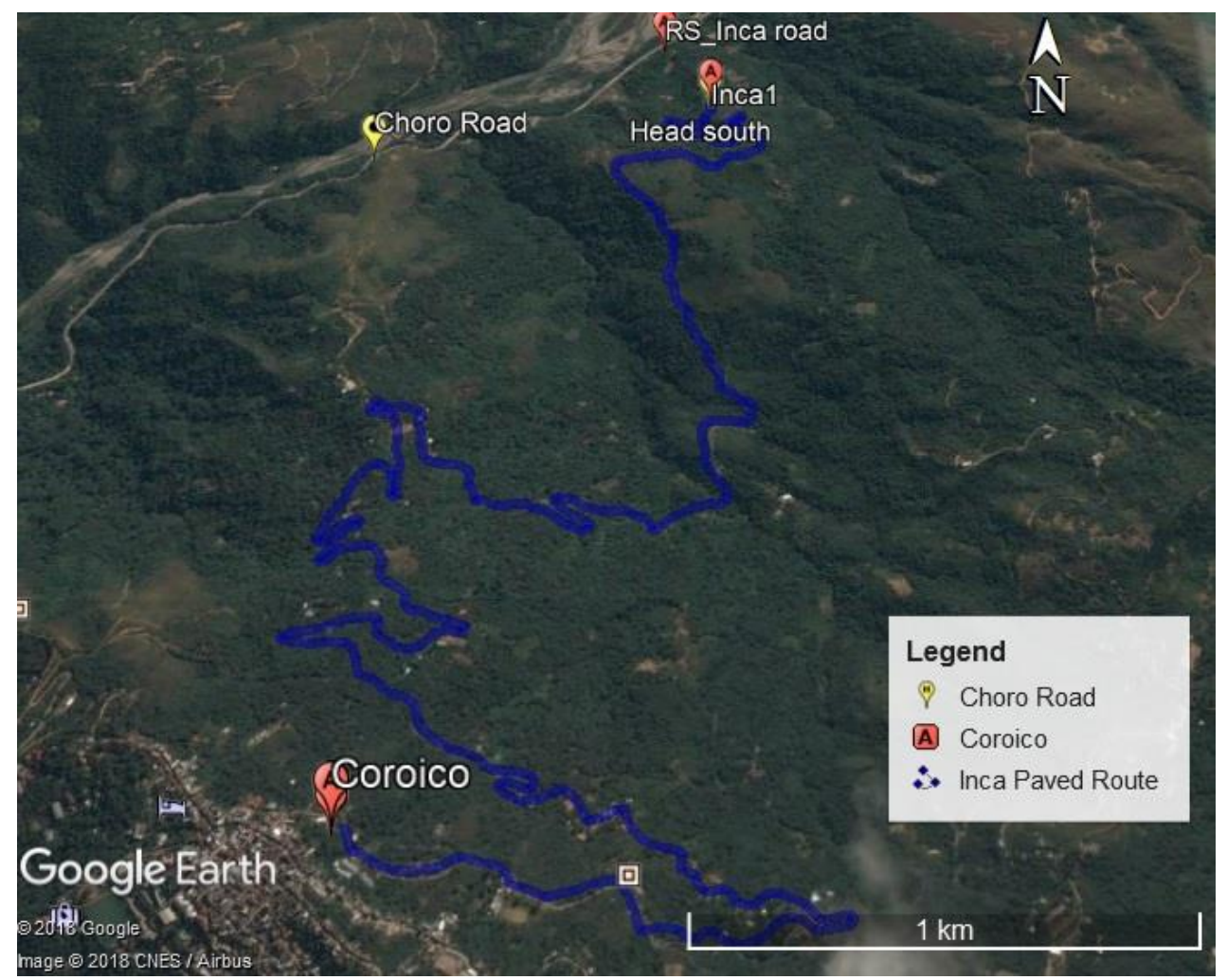

Fig. 4. The Inca trail from Coroico to Choro road down to the river valley.

The Transfăgărășan road is considered a unique functional attribute of the Făgăraș Geosystem which facilitates the matter, energy and information fluxes. It was built between 1970 and 1974 for strategic reasons generated by the Russian military invasion of Czechoslovakia in 1968. The Romanian military deflagrated 6250 tons of dynamite to dislocate the massive rocks (Moceanu, 2017). It has the longest (887 m) high altitude tunnel ( $2045 \mathrm{~m})$ that connects $80 \mathrm{~km}$ of dangerous mountain roads from the last Southern village of Căpătaneni to Cârtisoara in the North. It represents the world`s best road trip according to Top Gear (TopGear, 2010; Transfăgărășan, 2017; LosApos, 2018). 
The road construction works required 3.8 million tons of rock displacement, decreasing the shear strength of the slopes and triggering the dynamics of today`s geomorphological processes (Urdea, 2000; Urdea et al., 2009). Chiroiu et al. (2016) used the tree-ring techniques for the Northern Făgăraș slope stability determination. Based on dendrochronological analysis and the aerial photographs they proved that the deforestation activities associated to the Transfăgărășan road construction activated rockfalls and avalanches, unbalancing the Geosystem`s natural equilibrium. On the $17^{\text {th }}$ of April 1977 an avalanche killed 19 kids from Brukental Lyceum in Balea Lake.

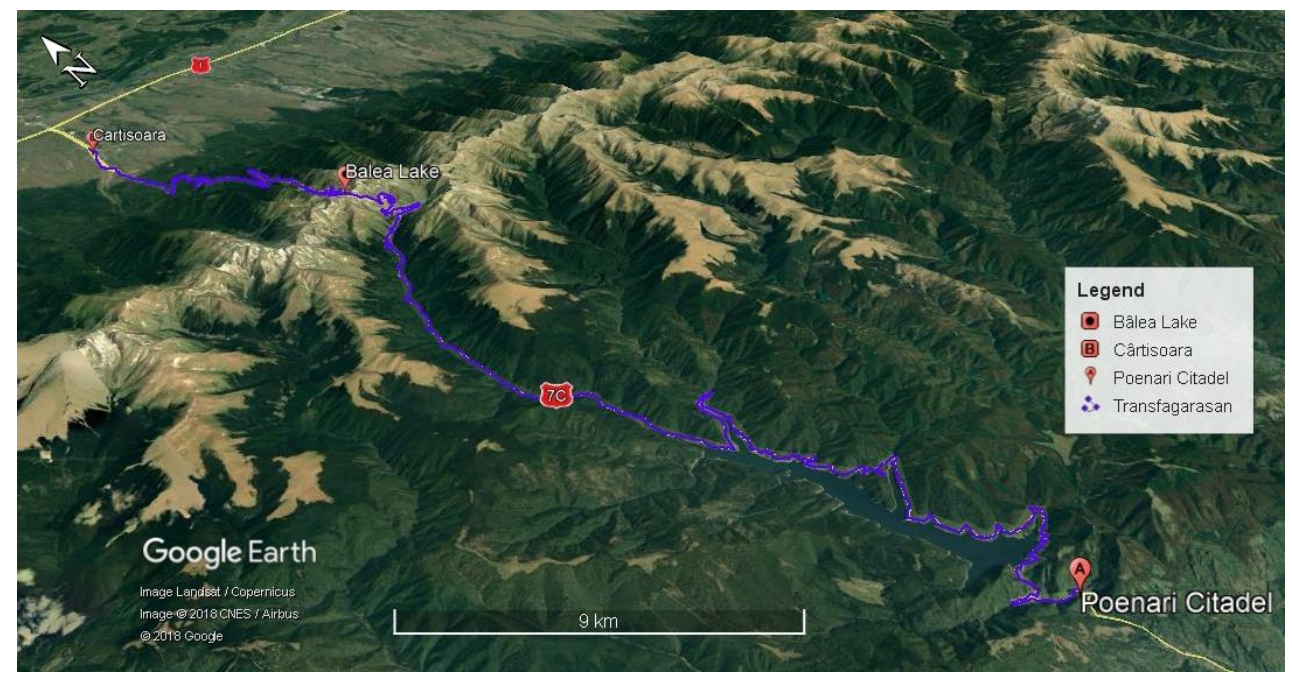

Fig. 5. The Transfăgărășan road from Poienari Castle to Cârtisoara village.

Many human lives were lost along the Transfăgărăşan route (Fig. 5), before, during and after the road construction. Căpătaneni's village name (căpătani meaning heads) is related to the bloody Posada battle from 1330s and the considerable number of skulls with fighting helmets found into the local grounds. The fights with Mehmet II Fatih throughout the year of 1462 determined Vlad Tepes`s wife to throw herself from a Poienari Citadel window thus generating the legend of Raul Doamnei (Lady`s River). Bram Stoker`s Dracula character was inspired by Vlad Tepes (the Impaler), the cruel Walachian prince (LosApos, 2018; Ernawati et al., 2018).The Transfăgărăşan cultural ecosystem benefits are associated with the Romanian national identity and the miorita (the little ewe) space. Miorita is an ancient pastoral ballad that defines the Romanian people`s strong attachment to the mountains (Babuts, 2000). The Romanian policy makers should focus more on people rights to explore the mountain gravel road networks and facilitate the development of cultural ecosystem services as services that integrate human built structures, individuals and social capital to initiate recreation and cultural distinctiveness production.

\subsection{Descending recreational activities and locals livelihood}

Our research offers comprehensive recommendations for the Romanian policy makers regarding the cultural ecosystem services and for the Bolivian government to extend the Death Road recreational model to other descending routes from the Yungas region. Our 
study proposes modern solutions for the local communities' future development in terms of new technology trend awareness and adoption.

The Yolosa, Río Selva, Coroico, Căpătaneni and Cârtisoara young hosts are aware of the local assets potential to be developed as tourism attractions. Smartphones technological advancements facilitate digital processing of any asset images. A photo can be transformed into a designed composition using the golden ratio mean. The better framed images are needed to transmit the locals' message to the international viewers. Any community asset image with the golden ratio is considerably better handled by the human mind. The brain sends the message that such an image is aesthetically pleasing (Patkar, 2015).

Analyzing the Airbnb phenomenon, Ert et al. (2016) emphasized the image relevance for the internet website credibility construction, demonstrating the Geosystem`s virtual imagery efficiency. The geographical space personalization with distinctive photos in transforming any Geosystem`s image, increases the Airbnb`s platform authenticity and functionality. Tussyadiah and Pesonen (2016) pointed out the local community`s importance in the host-guests social relationships. Sigala (2017) claims that Airbnb is leading the world's peer to peer accommodation system. Due to the modern smartphone application reviews and ratings, the North Yungas and the Făgăraș Geosystems` virtual image will attract more tourists, encouraging the local inhabitants to become superhosts and improve their livelihood (Wang and Nicolau, 2017; Liang et al., 2017; Gunter, 2018).

The Death Road and Transfăgărăşan are considered dangerous and untamed roads. Their stereotypical collective images have the same unique functional attributes that can be valorized in the future. Moreover, the Făgăraş Geosystem`s access routes to the main mountain ridge can develop cultural ecosystem services due to their richness in specific customs and ancient Romanian traditions. If developed accordingly, the Suapi route, the Inca`s paved trail from Coroico to the river valley and the Coripata-Rio Beni gravel road can considerably contribute to the local inhabitants' income increase in the future. The smartphone application advancements allow direct contact between tourists and community members, without La Paz travel agencies as intermediaries. In addition to the mountain biking experience, complementary activities such as whitewater rafting, canyoning, wild temperate forest or jungle exploration should be offered in order to keep tourist for another day in the region. Moreover, the local households can be adjusted and transformed to become exquisite Airbnb accommodations and provide extra-income.

\section{DISCUSSION}

The world`s mountains represent elaborate eco-social Geosystems where biodiversity has to be protected and the recreational activities developed in a sustainable way (Eriksson et al., 2012; Lai et al., 2016; Voda et al., 2017). Our developed Geomedia technique identifies the valuable assets of a geographical place evaluating the natural and cultural resources from a Geosystemic approach. The common and unique functionality of the Geosystem`s attributes were analyzed from a dynamic equilibrium perspective. The Geomedia means of promoting the natural and cultural values of a place should significantly increase the North Yungas locals experience in terms of balancing the conservation and recreational activities (Lai et al., 2016; Voda and Negru, 2015). Currently, the South American Death Road appears to be one of the world's most famous mountain bike descending route (Fig. 6) (Ridersmate, 2016; Verity, 2016). The cultural ecosystem services can provide benefits for the rural inhabitants of Căpătaneni and Cârtisoara villages situated in the Transfăgărășan proximity just as the Death Road is sustaining the benefits for the North Yungas 
Geosystem`s locals. The collective imagery of the North Yungas and the Făgăraș Geosystems was created with the social networks sharing capacity to maintain the information fluxes between the virtual and the real geographical spaces (Voda et al., 2014; Colvin et al., 2015). The social media contribution to the internet community building is undeniable, representing a place where the geographical locations virtual images are developed (Wheaton et al., 2016). Although it has been suggested that tourists flow can destroy the environmental physical capacity of support, it is generally agreed that the modern technology advancements can regulate and organize the information, matter and energy fluxes using the online smartphone applications.
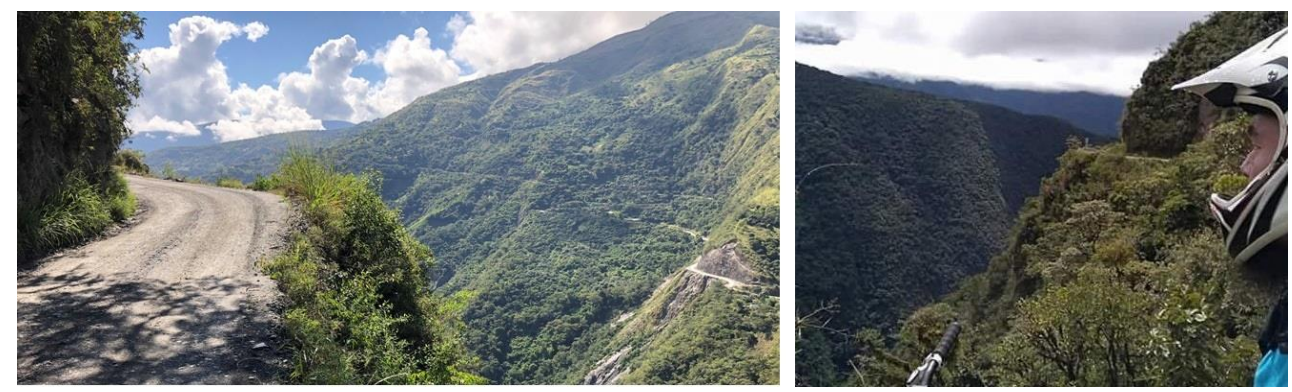

Fig. 6. The Death Road virtual image (Coripata-left and Coroico-right).

The Death Road frame model implementation in Transfăgărășan or other North Yungas Geosystem`s areas such as Suapi or Coripata has advantages and potential disadvantages. Community-based tourism success could reduce social inequality, encouraging the local inhabitants' identity expression and development. On the other hand, supplementary costs intervene when a local household is transformed into an Airbnb accommodation. Alternatively, biodiversity destruction might constitute a threat to the mountain ecosystem`s integrity. Overall, the community`s benefits are considered more valuable in most cases.

It is generally agreed that mountains are generating cultural values for humans. Firstly, the Romanian public access to the Fagaraș Geosystem`s mountain roads should be granted. Babuts (2000) emphasized the significant impact that Miorița virtual space has had on the Romanian psyche. Their value of wellbeing comes from seeing the mountain streams, the glacier lakes, the untamed scenic views. Secondly, the viewing sites placement and picnic areas establishment is compulsory. Thirdly, an integrated management and controlling system based on a collaboration among the local administration, the regional forest service, police enforcements and protected areas authorities need to be implemented.

Compared to the Romanian restrictive mountain laws, the Bolivian policy makers seem to better understand the positive effects of the cultural ecosystem services development in the North Yungas Geosystem.

\section{CONCLUSIONS}

Our main finding prove that any community can use Geomedia tools to create the virtual imagery of their living environment, scientifically illustrated through intelligently constructed photography of the Geosystem`s unique functional attributes. In the North Yungas, for example, the cultural goods are essentialized through the Death Road organized recreational activities, Yolosa, Rio Selva and Coroico locally produced food and drinks. 
The impressive technological evolution availability and the recent smartphone applications advancements based on the GPS capabilities for the geo-location and photos geotagging, support the semantic connotation identification of the special Geosystem`s assets. The North Yungas and the Făgăraș Geosystems `cultural ecosystem services benefits such as spiritual enrichment or aesthetic experiences are generating unquantifiable value and a different sense of wellbeing for the visitors that is indirectly reflected on the locals' welfare. The research results can be applied not only in the Făgăraș for the Transfăgărășan route development or in the North Yungas region to extend the mountain bike descending routes from Coroico to Coripata, down to the Beni river valley, but anywhere in the world's mountains, allowing the creation of the Death Road type recreational frameworks for the benefit of the poorest communities. The cultural ecosystem services development helped to the formation of a unique Death Road identity that can be reframed in other geographical locations.

There are a number of limitations to be considered, given the technical challenges of the Geosystem`s identity creation processes: one would be the North Yungas and the Făgăraș communities' specialized education in terms of sustainability and environmental balance maintenance between biodiversity conservation and recreational activities development, another, the poor access to technology. The sustainability of ecosystem services in the natural North Yungas Geosystem are not encumbered by governmental policy schemes such as Romanian Forest Law that forbids public access into the mountain gravel roads (Forest Law, 2015). Bolivia is progressing to assisting its impoverished rural inhabitants adopting various development programs to alleviate poverty (Fredette, 2017; World Bank, 2018).

Further research is required to analyze the local authorities' managerial capabilities of effectively coordinate sustainable recreation activities in the Cordillera Real and Făgăraș Mountains for their own community welfare. The Bolivian authorities should make the North Yungas Geosystem a focus of attention and properly valorize the potential of its unique attributes in the future.

\section{R E F E R E N C E S}

Babuts, N., (2000). `Miorita`: A Romanian Ballad in a Homeric Perspective. A Quaterly Journal in Modern Literatures, 54, 3-15, https://doi.org/10.1080/00397700009598285.

Baiocchi, V., Constantino, D., \& Vatore, F., (2017). Suitability of Averaging GPS/GNSS Paths to Build Geometrically Correct Digital Road. Geographia Technica, 12 (2), 1-9.

Beedie, P., (2003). Mountain guiding and adventure tourism: reflections on the choreography of the experience. Leisure Studies, 22:2, 147-167.

Blind Worlds, (2017). Accidents on Death Road. [Online]. https://www.blindworlds.com/publicacion/39405 [Accessed 24 December 2017].

Boyd, J., \& Banzhaf, S., (2007). What are ecosystem services? The need for standardized environmental accounting units. Ecol. Econo., 63, 616-626.

Buhalis, D., \& Law, R., (2008). Progress in tourism management: Twenty years on and 10 years after the internet: The state of eTourism research. Tourism Management, 29(4), 609-623.

Camino de la Muerte, (2009). Diariomotor. [Online]. https://www.diariomotor.com/2009/06/24/los-yungas-la-carretera-mas-peligrosa-del-mundo [Accessed 15 April 2018].

Chaco, (2009). Paraguyan prisoners building The Death Road. [Online]. http://www.cosasexclusivas.com/2009/06/la-carretera-de-la-muerte-en-bolivia.html [Accessed 5 May 2018].

Cherifi, B., Smith, A., Maitland, R., \& Stevenson, N., (2014). Destination images of non-visitors. Annals of Tourism Research, 49, 190-202. 
Colvin, R.M., Witt, G.B., \& Lacey, J., (2015). The social identity approach to understanding socio-political conflict in environmental and natural resources management. Glob. Environ. Change 34, 237-246.

Coroico, (2018). Tourism development in the Yungas Norte. [Online]. http://www.parkswatch.org/parkprofiles/pdf/conp_spa.pdf. [Accessed 3 May 2018].

Chiroiu, P., Ardelean, A.C., Onaca, A., Voiculescu, M., \& Ardelean, F. (2016). Assessing the antrophogenic impact on geomorphic processes using tree-rings: a case study in the Făgăraș Mountains (Romanian Carpathians). Carpathian Journal of Earth and Env.Sci., 11/1, 27-36.

Dickinson, J.E., Ghali, K., Cherrett, T., Speed, C., Davies, N., \& Norgate, S., (2014). Tourism and the smartphone app: capabilities, emerging practice and scope in the travel domain. Current Issues in Tourism, 17(1), 84-101.

Eriksson, L., Nordlund, A.M., Olsson, O., \& Westin, K., (2012). Recreation in Different Fores Settings: A Scene Preference Study. Forests, 3, 923-943.

Ernawati, N.M., Torpan, A., \& Voda, M., (2018). Geomedia role for mountain routes tourism development. Mesehe and Pisoiu Waterfall comparative study. Geographia Technica, 13 (1), 41-51.

Ert, E., Fleischer, A., \& Magen, N., (2016). Trust and reputation in the sharing economy: The role of personal photos in Airbnb, Tourism Management, 55, 62-73.

Fish, R., Church, A., \& Winter, M., (2016). Conceptualising cultural ecosystem services: A novel framework for research and critical engagement, Ecosyst. Serv., 21, 208-2017.

Forest Law 133, (2015). Motorised public acces into the National Forest Fund. [Online].http://www.dreptonline.ro/legislatie/legea_133_2015_modificare_lege_46_2008_codul _silvic.php, [Accessed 12 April 2017].

Fredette, C., (2017). Four reasons why Bolivia is poor. https://borgenproject.org/reasons-why-bolivia-is-poor/, [Accessed 10 August 2017].

Goeft, U., \& Alder, J., (2001). Sustainable mountain biking: A case study from the Southwest of Western Australia. Journal of Sustainable Tourism, 9(3), 193-210.

Gunter, U., (2018]. What makes an Airbnb host a superhost? Empirical evidence from San Francisco and the Bay Area. Tourism Management, 66, 26-37.

Haidu, I. (2016). What Is Technical Geography. Geographia Technica, 11(1), 1-5. DOI: 10.21163/GT_2016.111.01

Haukeland, J.V., Grue, B., \& Veisten, K., (2010). Turning national parks into tourist attractions: Nature orientation and quest for facilities. Scand. Journ. of Hos. and Tour., 10(3), 248-271.

Imboden, A., (2012). Between Risk and Comfort: Representations of Adventure Tourism in Sweden and Switzerland. Scand. Journ. of Hos. and Tour., 12:4, 310-323.

Inal, C., Kocak, O., Esen, O., Bulbul, S., \& Kizgut, R., (2017). Surveying and Mapping using Mobile Phone in Archaeological Settlements. Geographia Technica, 12 (2), 82-96.

Kumar, M., \& Kumar, P., (2008). Valuation of the ecosystem services: A psychocultural perspective. Ecol. Econo., 64, 808-819.

Lai, P.S.; Hsu, Y.C.; \& Wearing, S., (2016). A social representation approach to facilitating adaptive co-management in mountain destinations managed for conservation and recreation. J. Sustain. Tour., 24, 227-244.

Lapenta, F. (2011). Geomedia: on location-based media, the changing status of collective image production and the emergence of social navigation systems, Visual Studies, 26:1, 14-24.

Lew, A.A., \& Cheer, J., (2018). Lessons Learned: Globalization, Change, and Resilience in Tourism Communities. In J. Cheer and A.A. Lew, editors. Tourism, Resilience, and Sustainability: Adapting to Social, Political and Economic Change, 319-323. London: Routledge.

Liang, S., Schuckert, M., Law, R., \& Chen, C. C., (2017). Be a "Superhost": The importance of badge systems for peer-to-peer rental accommodations. Tourism Management, 60, 454-465.

LosApos. (2018). Transfăgărășan: world's best road trip according to Top Gear. [Online]. http://www.losapos.com/Transfăgărăşan, [Accessed on 4 June 2018].

Mac, I., (1996). Geomorfosfera și geomorfosistemele, Editura Presa Universitară Clujeană, Cluj Napoca. 
Martínez-Graña, A.M., Serrano, L., González-Delgado, J.A., Dabrio, C.J., \& Legoinha, P., (2017). Sustainable geotourism using digital technologies along a rural georoute in Monsagro (Salamanca, Spain), Int.J.Dig.Earth., 10:2, 121-138.

Martonne, E. (1917). The Carpathians: Physiographic Features Controlling Human Geography, Geographical Review, 3(6), 417-437, DOI: 10.2307/207688.

MEA. (2005). Millennium Ecosystem Assessment. In Ecosystems and Human Well-being: Synthesis; Island Press:Washington, DC, USA.

Milne, S., Grekin, J., \& Woodley, S. (1998). Tourism and the Construction of Place in Canada's Eastern Arctic. In Destinations: Cultural Landscapes of Tourism, ed. Greg Ringer (London, Routledge), $101-120$.

Moceanu, R. (2017). Documentar: Transfăgărășanul- drumul nostru prin paradis, [Online]. http://www.rador.ro/2017/09/20/documentar-Transfăgărăşanul-drumul-nostru-prin-paradis/, [Accessed on 3 December 2017].

Morckel, V., \& Terzano, K., (2014). The influence of travel attitudes, commute mode choice, and perceived neighborhood characteristics on physical activity. Journal of Physical Activity \& Health, 11(1), 91-98.

Newsome, D., \& Davies, Claire, (2009). A case study in estimating the area of informal trail development and associated impacts caused by mountain bike activity in John Forrest National Park, Western Australia. Journ. of Ecot., 8:3, 237-253.

Nicoara, Monica Elena \& Haidu, I., (2011). Creation of the roads network as a network data set within a geodatabase. Geographia Technica, 9(2), 81-86.

Park, S., \& Santos, C.A., (2017). Exploring the Tourist Experience: A Sequential Approach. Jour. of Trav.Res., 56(1) 16-27.

Patkar, M., (2015). Using the Golden Ratio in Photography for Better Composition. [Online]. https://www.makeuseof.com/tag/golden-ratio-photography/, July 23, 2015, [Accessed 12 August 2015].

Ridersmate, (2016). 6 of the Best: Our Favorites Extreme Mountain Bike Trails. [Online]. https://www.ridersmate.com/6-of-the-best-our-favourite-extreme-mountain-bike-trails/, [Accessed 15 March 2016].

Sanna, S., \& Eja, P., (2017). Recreational cultural ecosystem services: How do people describe the value? Ecosyst. Serv., 26, 1-9.

Schwanen, T., \& Kwan, M-P., (2008). The Internet, Mobile-phone and Space-time Constraints, Geoforum, 39 (3) 1362-1377.

Sherrouse, B.C., Clement, J.M., \& Semmens, D.J., (2011). A GIS application for assessing, mapping, and quantifying the social values of ecosystem services. Appl.Geogr. 31, 748-760.

Sigala, M., (2017). Collaborative commerce in tourism: Implications for research and industry. Current Issues in Tourism, 20, 346-355.

Sil, A., Rodrigues, A.P., Carvalho-Santos, C., Nunes, J.P., Honrado, J., Alonso, J., Marta-Pedroso, C., \& Azevedo, J.C., (2016). Trade-offs and synergies between provisioning and regulating Ecosystem Services in a mountain area in Portugal affected by landscape change. Mt. Res. Dev. $36,452-464$.

The Death Road, (2018). Biker informations. [Online]. http://www.freebikesbolivia.com/index.php/es/varios/historia-del-camino-de-la-muerte

[Accessed 8 March 2018].

Transfăgărășan. (2017). Povestea trista a Transfăgărășanului, 20.09.2017, www.descopera.ro [Accessed 8 November 2017].

Tussyadiah, I.P., \& Pesonen, J., (2016). Impacts of Peer-to-Peer Accommodation Use on Travel Patterns. Journal of Travel Research, 55(8) 1022-1040.

UN DESA. (2017). United Nations Department of Economic and Social Affairs/Population Division. International Migration Report 2017.2 [Online]. www.un.org/en/development/MigrationReport2017 [Accessed 14 January 2018].

UNDP. (2016). United Nations Development Programme. Human Development Reports. [Online].http://hdr.undp.org/en/home [Accessed 12 May 2017]. 
Urdea P., (2000). The geomorphological risk in Transfăgărășan Highway area. Studia Geomorphologica Carpatho-Balcanica, Vol.XXXIV.

Urdea, P., Török-Oance, M., Ardelean, M., Vuia, F., \& Voiculescu, M., (2009). Geomorphological aspects of the human impact in the alpine area of the Southern Carpathians (Romania). Croatian Geographic Bulletin (71), No.1, 19-31.

Yungas, (2018). La Paz connection to The Yungas Region. [Online]. http://blog.global-exchange.com/camino-de-la-muerte-bolivia/ [Accessed 11 March 2018].

Verity, Rachel, (2016). From the gnarly to the near impossible - could you handle any of these? 7 of the scariest bike trails in the world, 3 May 2016. [Online]. https://www.redbull.com/se-en/7-of-the-scariest-mountain-bike-trails-in-the-world, [Accessed 5 May 2016].

Voda, M., (2013). The role of Geospatial Technologies, Geographic Information and ICT in promoting rural communities sustainable development in Transylvania. Acade. Sci. J. Geogr. Series, 3, 9095.

Voda, M., Moldovan, L., Torpan, A., \& Henning, A., (2014). Using GIS for mountain wild routes assessment in order to qualify them for tourism valorisation. Geographia Technica, 9, 101-108.

Voda, M., \& Negru, R., (2015). Geomedia role in Mures Valley Castles tourism development between Ogra and Brancovenesti. Acad. Sci. J. Geogr. Ser. 6, 63-70.

Voda, M., Torpan, A., \& Moldovan, L., (2017). Wild Carpathia Future Development: From Illegal Deforestation to ORV Sustainable Recreation. Sustainability, 9(2254), 1-11.

Walter, J., (1982). Social limits to tourism, Leisure Studies, 1, 295-304.

Wang, D., \& Nicolau, J.L., (2017). Price determinants of sharing economy based accommodation rental: A study of listings from 33 cities on. International Journal of Hospitality Management, $62,120-131$.

Webber, P., (2007). Managing mountain biking, IMBA's guide to providing great riding. Boulder, CO, USA: International Mountain Bicycling Association.

Wescott, F., \& Andrew, M.E., (2015). Spatial and environmental patterns of off-road vehicle recreation in a semi-arid woodland. Appl. Geogr., 62, 79-106.

Wheaton, M., Ardoin, N.M., Hunt, C., Schuh, J.S., Kresse, M., Menke, C., \& Durham, W., (2016). Using web and mobile technology to motivate pro-environmental action after a nature-based tourism experience. J. Sustain. Tour., 24, 594-615.

Wimpey, J., \& Marion, J.L., (2011). A spatial exploration of informal trail networks within Great Falls Park, VA. J. Environ. Manag., 92, 1012-1022.

Winters, M., Davidson, G., Kao, D., \& Teschke, K., (2011). Motivators and deterrents of bicycling: Comparing influences on decisions to ride. Transportation, 38(1), 153-168.

World Bank, (2018). The World Bank in Bolivia. [Online].http://www.worldbank.org/en/country/bolivia [Accessed 5 May 2018].

Zheng, Y-T., Zha, Z-J., \& Chua, T-S., (2010). Research and applications on georeferenced multimedia: a survey. Multimedia Tools Applications, 51, 77-98. 